Article

\title{
An Economic, Energy, and Environmental Analysis of PV/Micro-CHP Hybrid Systems: A Case Study of a Tertiary Building
}

\author{
José Manuel Salmerón Lissén ${ }^{1, *}$, Laura Romero Rodríguez ${ }^{1}$, Francisco Durán Parejo ${ }^{1}$ \\ and Francisco José Sánchez de la Flor ${ }^{2}$ (D) \\ 1 Grupo de Termotecnia, Escuela Superior de Ingenieros, Universidad de Sevilla, Camino de los \\ Descubrimientos S/N, 41092 Sevilla, Spain; lrr@us.es (L.R.R.); francisco.flor@gm.uca.es (F.D.P.) \\ 2 Escuela Superior de Ingeniería, Departamento de Máquinas y Motores Térmicos, Universidad de Cádiz, \\ Avda, Universidad de Cádiz, nº 10, 11519 Cádiz, Spain; francisco.flor@uca.es \\ * Correspondence: jms@us.es
}

Received: 11 October 2018; Accepted: 5 November 2018; Published: 7 November 2018

check for updates

\begin{abstract}
Our present standard of living depends strongly on energy sources, with buildings being a primary focus when it comes to reducing energy consumption due to their large contribution, especially in tertiary buildings. The goal of the present study is to evaluate the performance of two different designs of hybrid systems, composed of natural gas engines and photovoltaic panels. This will be done through simulations in TRNSYS, considering a representative office building with various schedules of operation $(8,12$, and $24 \mathrm{~h}$ ), as well as different climates in Spain. The main contributions of this paper are the evaluations of primary energy-consumption, emissions, and economic analyses for each scenario. In addition, a sensitivity analysis is carried out to observe the influence of energy prices, as well as that of the costs of the micro-CHP engines and PV modules. The results show that the scenario with the conventional system and PV modules is the most profitable one currently. However, if electricity prices are increased in the future or natural gas prices are reduced, the scenario with micro-CHP engines and PV modules will become the most profitable option. Energy service engineers, regulators, and manufacturers are the most interested in these results.
\end{abstract}

Keywords: distributed generation; hybrid systems; PV; micro-CHP; microcogeneration; TRNSYS

\section{Introduction}

Within the scientific community, there is growing agreement that climate change is real and a threat to humankind. Due to the realization that the energy sources required for maintaining our present standard of living are limited, the concept of energy efficiency is receiving increased attention. Many studies have proposed different alternatives to implement technologies that are able to produce energy more efficiently, while diminishing its environmental impact at the same time. Among these, we can find different renewable energy technologies such as Photovoltaics (PV), wind or solar thermal energy, and Combined Heat and Power (CHP) systems. The number of studies that combine the use of these technologies (hybrid systems) is increasing, but there are many aspects that still need to be further investigated, such as the integration of $\mathrm{CHP}$ with renewable technologies.

\subsection{Literature Review}

A review of previous literature on hybrid systems has shown that one of the most common links is the analysis of stand-alone systems in which one of the main the differences between different 
studies is the focus on generation systems that can go from an internal combustion engine, to fuel cells, photovoltaics, or combinations of the previous factors that lead to hybrid systems [1-15]. Conversely, other studies only evaluate certain components $[6,14,16,17]$, while others do not develop an exhaustive analysis of the Life Cycle Costs (LCC), emissions, and/or primary energy-consumption $[3,4,6]$, which will be analyzed in detail in the present study. Also, for instance, the authors in reference [18] determine the technical, systematic, and financial requirements needed to allow a city or community to become independent of the utilization of traditional energy sources, using hybrid energy-systems.

The relationship between environmental and economic aspects regarding hybrid or photovoltaic systems has also been studied in the literature. A dynamic analysis of a hybrid energy storage system in this regard is included in reference [19], whereas reference [20] confirms the environmental and economic advantages of PV sources as an alternative to fossil fuels. However, performing accurate dynamic analyses of hybrid systems is not a trivial task. For this reason, a simplified method for an optimal sizing of hybrid systems combined with renewable energy is included in reference [21], claiming that adequate sizing frequently requires very detailed simulation and demand/supply analyses.

Buildings are among the sectors with the greatest potential for improvement in their energy efficiency. Therefore, among the range of different technologies, CHP systems are very important for producing energy more efficiently in buildings, especially in countries where the implementation of these energy production technologies is reduced to a few practical experiences. Nevertheless, the vast majority of previous studies put the focus on residential buildings $[5,10,11,13,14,16,22-31]$ in which the major difference between them is the location, or in neighborhoods or urban or rural areas [1,2,4,15,32-36], and only some of them focus on industries: brewers [37], water disinfection [38,39], or greenhouses [40], for instance. In conclusion, recent studies on 30 buildings have been found in the literature, of which 23 are residential buildings in urban areas and eight residential buildings in rural areas; five are industrial buildings and only two cases are focused on office buildings. Therefore, a lack is identified in the study of this building typology. The methodology and results of these works related to office buildings are described in detail below.

With respect to tertiary buildings, Fani and Sadreddin [41] analyze educational office buildings that implement solar-assisted Combined Cooling, Heat, and Power (CCHP) systems, but only in one climate (Tehran, Iran) and with fixed internal gains. They conclude that due to low electricity tariffs and the relatively expensive price of new systems, the daily cost of the proposed systems is always higher than the conventional system is particularly interesting. Yousefi et al. [42] carry out a multi-objective optimization of component sizing of a hybrid CCHP microgrid to meet the electric needs and the heating and cooling loads of an office building in Tehran. A critical review [43] states that it is very important to analyze how hybrid energy-systems can be used to decrease the energy consumption, but also to improve the economic and environmental operation in office buildings, as the authors intend to do in the present work.

\subsection{Aim of the Study}

In this paper, we innovatively analyze diverse configurations of hybrid systems, including PV panels, or PV combined with natural gas internal combustion engines in an office building in Spain. In order to analyze the solutions from different perspectives, we have compared the primary energy-consumption, final energy consumption, $\mathrm{LCC}$, and $\mathrm{CO}_{2}$ emissions of each configuration with that of a conventional case. Moreover, the best solution in terms of each of the previous indicators has been identified as a function of the climate by carrying out the simulations in five representative climates in Spain, which are also representative climates of the Mediterranean region of Europe [44]. Another novelty is the evaluation of the best solution depending on the hours of operation of the building $(8,12$, and $24 \mathrm{~h}$ a day) and the non-constant internal loads assumption. Finally, another major contribution of this paper is the inclusion of a sensitivity analysis regarding the energy prices, to evaluate their importance to increase the economic feasibility of hybrid systems. Given that 
the authors of this article have published a complementary study for residential buildings [45], the differences and similarities of the optimal solutions have also been compared in these two building typologies.

This paper is structured as follows. In Section 2, the methodology of the study will be explained, including information about the case studies and the implementation of the alternatives that will be evaluated. Then, Section 3 will analyze in detail the results of the simulations, as well as include a sensitivity analysis regarding the electricity and natural gas prices, as well as those of the Micro-CHP engines and photovoltaic system. Finally, we conclude with a brief summary in Section 4.

\section{Method: Characteristics of the Study}

In this section, the installation and case study of the present work will be described, together with the different configurations of hybrid systems that will be evaluated, equipment sizing, calculations needed, as well as the model created in the TRNSYS software version 17 (University of Wisconsin-Madison, Madison, WI, USA).

\subsection{Description of the Installation}

The present study revolves around the design of an innovative energy production system (electricity, heating, and cooling) for an office building. As noted in the introduction, very few research studies have been carried out on hybrid systems that link solar photovoltaic panels with a $\mu$-CHP system in tertiary buildings. Our novel proposal is to use a $\mu$-CHP hybrid system that combines photovoltaic internal combustion engines and natural gas engines to supply most of the energy for the building of the case study during a whole year. This proposal differs from that of other studies. For instance, the proposal is not stand-alone such as those in references [3,6-12].

In addition, some aspects that many studies fail to bear in mind are considered, such as the use of a software that allows one to make adjustments in the system in an easy way. The LCC of the different proposed schemes have also been calculated in the same way as reference [9]. Thus, it is possible to compare the results of the innovative designs with those of the conventional base-case scenario, in which electricity is obtained from the grid and natural gas is used in the heating boilers. Last of all, calculations of the emissions for each configuration have been performed, in concordance with papers on emissions savings such as those in references $[13,14]$.

\subsection{Chosen Alternatives}

Different configurations of hybrid systems have been considered in this study with the purpose of analysing their impact on the potential energy and cost savings that may be achieved when supplying all the necessary energy for the building. The proposed schemes have been modelled using the software TRNSYS 17, which allows one to make straightforward alterations of any device included in the system, facilitating the task of changing parameters, connections, and configurations. Most parameters necessary for the simulations would not affect the assessments in a perceptible way. However, others are paramount from an energetic and/or economical point of view. The alternatives that have been considered are as follows:

- Conventional case: the installation is simulated assuming that all the required electricity (electricity needs of the building, pumps, and chillers) will be obtained from the grid. On the other hand, heating will be provided by boilers running on natural gas.

- Photovoltaic panels alternative: same as the previous scenario but also including a set of 380 PV panels located on the rooftop of the building, which will produce part of the required electricity.

- Micro-CHP engines + photovoltaic panels alternative (hybrid system): same as the previous scenario but also including micro-CHP natural gas engines for electricity production. In this case, the residual thermal energy of the engines is used to reduce the natural-gas consumption of the boiler. 


\subsection{Case-Study Building and Climate}

The building subject of the current application is a six-storey office building, chosen as much representative as possible of the current Spanish built environment. The facade with the largest surface is oriented to the south, and the building has a total conditioned area of $6629 \mathrm{~m}^{2}$. The average density of the internal gains of the building is $7.5 \mathrm{~W} / \mathrm{m}^{2}$, both for lighting and equipment. The same building will be studied under three different operating schedules: 8,12 , and $24 \mathrm{~h}$. In this way, the influence of this variable on the results obtained will be analyzed, allowing one to obtain important conclusions for office buildings depending on the operating schedules.

In addition, the simulations will be carried out in five different locations of Spain: the climatic zones A3, B4, C2, D3, and E1 (Cádiz, Seville, Barcelona, Madrid, and Burgos, respectively). These locations are representative of the main Spanish climates [44].

\subsection{Building Energy Needs}

Both the heating and cooling energy needs of the building depend on the climate where it is placed. Therefore, in order to obtain the results of the energy needs, simulations of the building for five different climatic zones have been carried out using the LIDER version 2009 (Government of Spain, Madrid, Spain) thermal simulation tool [46]. Consequently, the hourly space cooling and heating needs were obtained for each of those cases. The electricity needs have been obtained through the density of internal sources of lighting and equipment. The summary of the annual electricity, cooling, and heating-energy needs of the building with a $24 \mathrm{~h}$ operating schedule for each climatic zone is shown in Table 1.

Table 1. Annual electricity, heating, and cooling needs of the building for each climate.

\begin{tabular}{cccc}
\hline Climate Zone & Electricity Needs $\left[\mathbf{k W h} / \mathbf{m}^{\mathbf{2}}\right]$ & Heating Needs $\left[\mathbf{k W h} / \mathbf{m}^{\mathbf{2}}\right]$ & Cooling Needs $\left[\mathbf{k W h} / \mathbf{m}^{\mathbf{2}}\right]$ \\
\hline A3 & 131.4 & 21.68 & 89.19 \\
B4 & 131.4 & 32.06 & 97 \\
C2 & 131.4 & 57.62 & 52.18 \\
D3 & 131.4 & 87.93 & 68.68 \\
E1 & 131.4 & 121.68 & 29.39 \\
\hline
\end{tabular}

\subsection{Operating Protocol}

The novel proposal of hybrid systems in the present study aims to shed some light onto which configurations are more convenient depending on the climatic characteristics and the schedule of operation of the building. The characteristics of the complete system proposed for this study (Micro-CHP engines + photovoltaic panels) are as follows:

- The electricity will be produced by two Internal Combustion Engines of $100 \mathrm{kWe}$ each, which run on Natural Gas and work in parallel. The number of engines activated depends on the total electricity demand for that time-step. The first engine will always work as much as possible, and the second engine will be used as backup. The reason for this is to optimise the hours of operation of the engines; (this is further discussed in the previous study of the authors [45]). To prevent the engines from running at their minimum power (therefore, with a low energy performance), the electricity in these situations will be obtained from the electric grid. Subsequently, the buildings will not be isolated.

- In the process of generating electricity, the engines also produce heat, which will be used to decrease the energy required by the heating boiler in charge of covering the heating demand of the building.

- The cooling system will be electric and will consist of heat-pump air-cooled water-chillers.

- In this paper, the option of selling the excess of electricity production of the PV to the grid will not be considered, because the majority of the energy will be consumed within the building 
simultaneously (buildings operate during the day). Batteries arrays to store electricity are also outside of the scope of this study.

\subsection{Equipment Sizing}

Many aspects have been considered to carry out the sizing of the different elements in the proposed schemes. In the case of the air-cooled chillers, the peak loads of the building cooling demand were considered as well as the variations in the performance due to partial load factors and the surrounding temperature. For the auxiliary heating boilers, the design covered at least $90 \%$ of the heating hours, which vary depending on the climatic zone.

On the other hand, the sizing of the PV field considered the minimum and maximum voltage of the panels due to outdoor temperature differences, with the goal of enhancing the quantity of panels. In addition, the tilt angle of the PV panels was also selected equal to the location latitude minus $10^{\circ}$, in order to maximise the annual electricity production of the PV field. The PV modules have a southern orientation. Last of all, due to the intricacies when dimensioning the size of the water tanks, five different volumes were considered, to assess their influence on the performance of the installation.

\subsection{Calculations Needed}

Many outcomes can be obtained from the simulations. For the purposes of the present study, the most important are the following:

- Annual PV production.

- Annual heating consumption.

- Annual energy consumption of the engines.

- Annual electricity consumption (pumps, cooling, and building electricity demand).

Once this information is known, it is possible to carry out all the calculations in order to obtain the fuel consumption of each component. Moreover, the total primary energy-consumption, total operation costs, and total $\mathrm{CO}_{2}$ emissions can be calculated.

The emissions and primary energy factors (obtained from [47]) and the energy costs that have been taken into account are as follows:

- $\quad$ Grid-electricity primary-energy factor [kWh/kWh]: 2.4

- Natural gas primary-energy factor $[\mathrm{kWh} / \mathrm{kWh}]: 1.19$

- $\quad$ Grid electricity emission factor: $0.357 \mathrm{kgCO}_{2} / \mathrm{kWh}$

- $\quad$ Natural-gas emission factor: $0.25 \mathrm{kgCO}_{2} / \mathrm{kWh}$

- $\quad$ Electricity price: $0.209 € / \mathrm{kWh}$

- Natural gas price: $0.068 € / \mathrm{kWh}$

Another one of the objectives of this study has been to assess the LCC for each case. A time span of 30 years has been considered. The costs considered include the capital investment, operation, replacement, and maintenance costs. The following equation was used in order to obtain the LCC:

$$
L C C=\text { Initial }_{\text {investment }}+\text { Costs }_{\text {replacement }}+\left(\text { Costs }_{\text {operation }}+\text { Costs }_{\text {maintenance }}\right) \cdot \sum_{t=1}^{30} \frac{1}{(1+r)^{t}}
$$

in which " $r$ " is the inflation rate (3\%) and " $t$ " is the year.

\subsection{TRNSYS Implementation}

In this section, the way in which the system was implemented in TRNSYS [48] in order to carry out the simulations is going to be explained. TRNSYS is a simulation program frequently used by many studies to simulate transient systems. It is also used to confirm new energy-concepts, including control strategies. The main reason why TRNSYS is frequently used in the literature is that it allows 
one to adjust all parameters in a very flexible way and to develop models that reflect reality in an accurate way. In comparison with other methodologies, TRNSYS is capable of capturing the dynamics of thermal energy-systems more precisely.

\subsubsection{Electric Subsystem}

The electric part of the system, which consists of several elements, was modelled in TRNSYS as follows:

- Photovoltaic panels: The technical sheets of the manufacturer were used to adapt type 94. The PV panels are associated with the type that comprises the climatic data (Type 9).

- Inverter: As for the PV panels, the manufacturer's technical data are used to adapt Type 175 to the needs of the proposed system.

- Air-cooled chillers: to consider the performance variations due to partial load and outdoor air temperature fluctuations, a combination of TRNSYS types 42 and 43 was used. The cooling demand is indicated through a Data Reader (Type 9).

- Balance tool: A calculator, capable of obtaining for each time-step the balance between the required electricity for the building, the energy consumption of the pumps, the electricity required by the air-cooled water chiller, and the electricity produced by the PV field, was included. After performing the energy balance, a signal is sent to the natural-gas engines to indicate to them the quantity of energy they need to produce, as well as how many engines need to be operational.

- Micro-CHP engines: Due to its frequent implementation and consistency, Type 120 was used. Originally aimed to simulate a diesel engine, nowadays this type allows one to switch the type of fuel to natural gas. Once Type 120 knows at each timestep how much electricity has to be produced, it provides the output data of fuel consumption, electric efficiency, fuel efficiency, and the produced residual-heat. This waste heat will be used to decrease the fuel needs of the space-heating boiler.

\subsubsection{Heating Subsystem}

In this section, the thermal part of the installation responsible for satisfying the heating needs is shown. It is composed of the following elements:

- Hot water storage tank: considering no auxiliary heating elements, Type 4 has been used. Water stratification is taken into account by dividing the height of the tank into six nodes.

- Auxiliary space-heating boiler: Type 6, which corresponds to a boiler of a specified maximum capacity, was used with an output temperature of $50{ }^{\circ} \mathrm{C}$ and a capacity that depends on the climate. The boiler efficiency was set to $92 \%$.

- Waste heat recovery from the CHP engines: after consulting data in the manufacturer's datasheet, the present study makes the assumption that $60 \%$ of the residual heat of the engines is recoverable. An innovative element that acts as a heat exchanger has been designed in order to assess which part of the residual heat is going to be supplied to the heating storage tank.

- Controller and pumps: Type 114 was chosen for the pumps. Pumps 1 and 2 (see Figure 1) will only be activated during winter months, when the building demands heating. The water temperature difference in the radiators is calculated using a calculator and as a function on the energy needs of each time-step. The controller, which uses Type 2, decides when pump 1 has to operate to recover the residual heat of the engines (when the temperature of the accumulation tank is less than $\left.50^{\circ} \mathrm{C}\right)$.

- Other elements: a data reader (Type 9) is needed to provide the heating demand data of the building. In addition, several elements are required for assessing the consumption of the pumps, the heating consumption, and the heating energy balances. 


\subsubsection{Tank Volume Optimization}

After the proposed systems were modelled in TRNSYS, five alternatives were considered for the heating tank volume, with the purpose of evaluating its influence on the results of the proposed designs $\left(1,2,3,4\right.$, and $\left.5 \mathrm{~m}^{3}\right)$. An optimization of the tank volume was therefore pursued to minimise the total primary-energy consumption, $\mathrm{CO}_{2}$ emissions, and LCC for each of the analyzed configurations and each climatic zone.

\subsubsection{TRNSYS System Diagram}

In Figure 1, the diagram of the system modelled in TRNSYS for the configuration that uses both $\mathrm{PV}$ modules and CHP engines is shown.

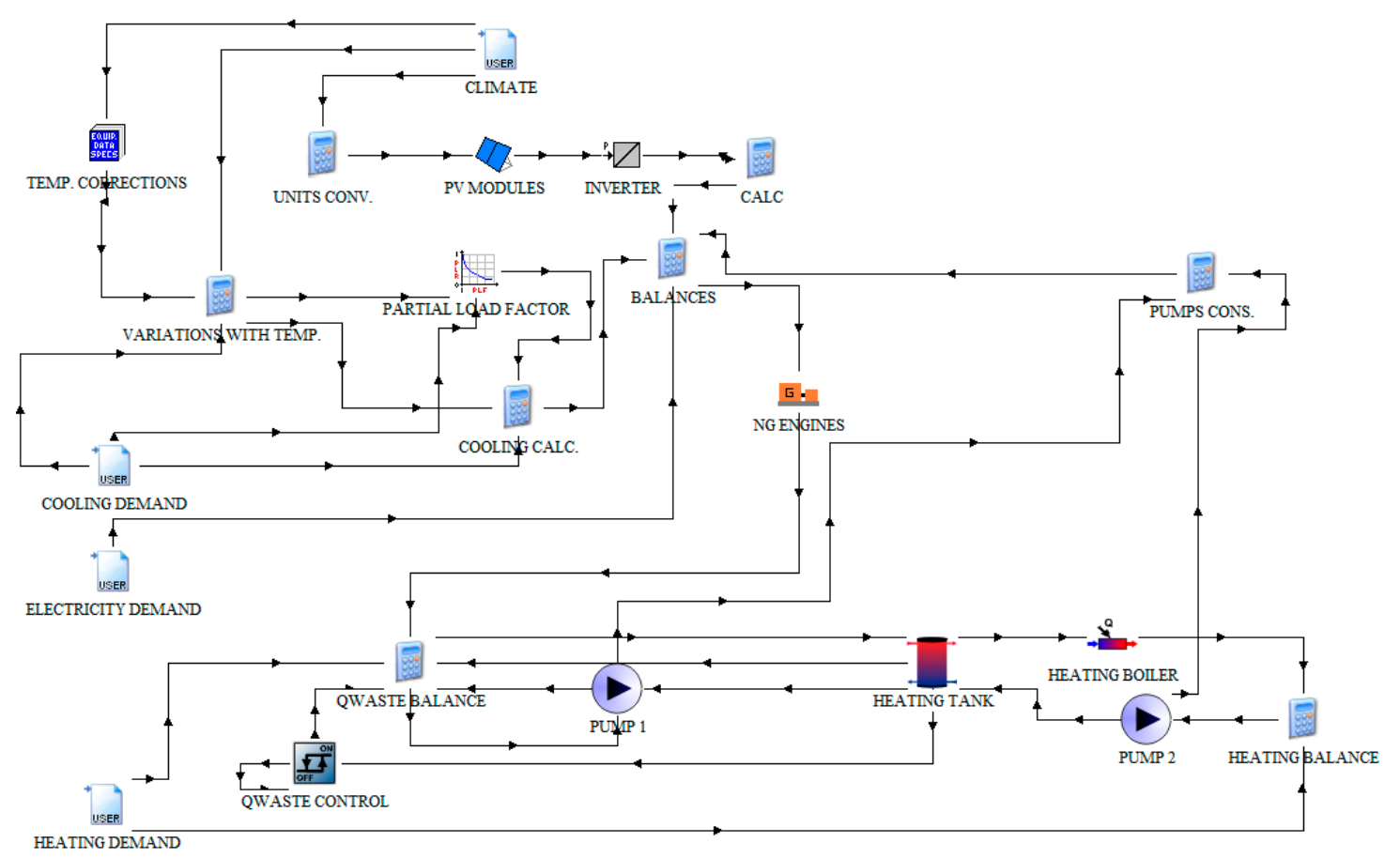

Figure 1. Interconnections between types for the whole system.

\section{Analysis of Results}

\subsection{Calculations}

A total of 225 simulations were carried out: three different configurations (conventional case, conventional and PV modules, PV modules, and CHP engines), five tank volumes $\left(1,2,3,4\right.$, and $\left.5 \mathrm{~m}^{3}\right)$, three different building hours of operation $(8,12$, and $24 \mathrm{~h})$, and five climatic zones (A3, B4, C2, D3, and E1). Once all the simulations were performed, the annual aggregated consumptions of the main elements of the system were obtained for each case.

First, it should be mentioned that once we had analysed the results, we could detect that the planned PV system only produced excess of electricity a few hours per year. Therefore, as mentioned before, the sale of electricity is not interesting, given these results and all the intricacies regarding the current regulatory situation of PV in Spain.

In addition, the simulations were carried out for the different proposed heating-tank sizes. There were differences in the results of each case; nevertheless, they were very minor in comparison with the total energy-consumption of the system. However, the results revealed that $5 \mathrm{~m}^{3}$ for the heating tank was the most favourable solution. Therefore, Tables $2-4$ summarise the results when using the $5 \mathrm{~m}^{3}$ water tank: 
Table 2. Annual results for the building with the $24 \mathrm{~h}$ operating schedule.

\begin{tabular}{ccccc}
\hline & Climate & Conventional & PV & $\mu$-CHP Engines + PV \\
\hline & A3 & 342.12 & 277.76 & 368.37 \\
Primary energy-consumption & B4 & 380.76 & 317.78 & 413.22 \\
$\left(\mathrm{kWh} / \mathrm{m}^{2}\right)$ & C2 & 375.80 & 319.73 & 398.27 \\
& D3 & 426.10 & 370.43 & 472.46 \\
& E1 & 443.89 & 392.05 & 484.86 \\
\hline & A3 & 51.35 & 41.77 & 76.77 \\
$\mathrm{CO}_{2}$ Emissions $\left(\mathrm{kg} / \mathrm{m}^{2}\right)$ & B4 & 58.02 & 48.65 & 86.10 \\
& C2 & 59.10 & 50.76 & 83.14 \\
& D3 & 69.13 & 60.84 & 98.84 \\
& E1 & 73.76 & 66.04 & 101.41 \\
\hline $\mathrm{LCC}\left(€ / \mathrm{m}^{2}\right)$ & A3 & 585.27 & 521.13 & 613.66 \\
& B4 & 643.25 & 581.48 & 665.61 \\
& C2 & 614.90 & 564.91 & 644.59 \\
& D3 & 677.28 & 627.97 & 727.47 \\
& E1 & 686.54 & 643.88 & 739.68 \\
\hline
\end{tabular}

Table 3. Annual results for the building with the $12 \mathrm{~h}$ operating schedule.

\begin{tabular}{ccccc}
\hline & Climate & Conventional & PV & $\mu$-CHP Engines + PV \\
\hline & A3 & 199.12 & 134.76 & 173.97 \\
Primary energy-consumption & B4 & 222.60 & 159.63 & 203.77 \\
$\left(\mathrm{kWh} / \mathrm{m}^{2}\right)$ & $\mathrm{C} 2$ & 213.09 & 157.02 & 188.52 \\
& D3 & 239.66 & 183.99 & 220.67 \\
& E1 & 248.50 & 196.84 & 226.79 \\
\hline & A3 & 29.79 & 20.22 & 34.81 \\
$\mathrm{CO}_{2}$ Emissions $\left(\mathrm{kg} / \mathrm{m}^{2}\right)$ & B4 & 33.62 & 24.25 & 40.95 \\
& $\mathrm{C} 2$ & 33.24 & 24.90 & 37.82 \\
& D3 & 38.41 & 30.13 & 44.62 \\
& E1 & 40.97 & 33.29 & 45.89 \\
\hline $\mathrm{LCC}\left(€ / \mathrm{m}^{2}\right)$ & A3 & 343.89 & 279.75 & 406.59 \\
& B4 & 381.66 & 319.89 & 442.05 \\
& $\mathrm{C} 2$ & 352.97 & 302.98 & 421.70 \\
& D3 & 387.54 & 338.23 & 458.10 \\
& E1 & 388.71 & 346.24 & 463.16 \\
\hline
\end{tabular}

Table 4. Annual results for the building with the $8 \mathrm{~h}$ operating schedule.

\begin{tabular}{ccccc}
\hline & Climate & Conventional & PV & $\mu$-CHP Engines + PV \\
\hline & A3 & 156.22 & 91.86 & 114.33 \\
Primary energy-consumption & B4 & 172.21 & 109.24 & 136.22 \\
$\left(\mathrm{kWh} / \mathrm{m}^{2}\right)$ & C2 & 169.62 & 113.56 & 131.46 \\
& D3 & 189.62 & 133.95 & 155.25 \\
& E1 & 198.17 & 146.51 & 163.62 \\
\hline & A3 & 23.38 & 13.81 & 21.83 \\
$\mathrm{CO}_{2}$ Emissions $\left(\mathrm{kg} / \mathrm{m}^{2}\right)$ & B4 & 26.05 & 16.68 & 26.50 \\
& C2 & 26.54 & 18.20 & 25.36 \\
& D3 & 30.48 & 22.19 & 30.41 \\
& E1 & 32.72 & 25.04 & 32.14 \\
\hline LCC $\left(€ / \mathrm{m}^{2}\right)$ & A3 & 270.96 & 206.81 & 344.14 \\
& B4 & 296.40 & 234.63 & 368.88 \\
& C2 & 281.10 & 231.11 & 362.27 \\
& D3 & 306.86 & 257.55 & 389.28 \\
& E1 & 310.11 & 267.65 & 396.93 \\
\hline
\end{tabular}




\subsection{Comparison between Design Alternatives}

Two sets of graphs that allow the evaluation between the different climates and designs are shown in Figure 2. They represent in the $y$-axis the $\mathrm{LCC}, \mathrm{CO}_{2}$ emissions, and primary energy-consumption. These results are analysed in the Sections 3.2.1-3.2.4 in more detail.
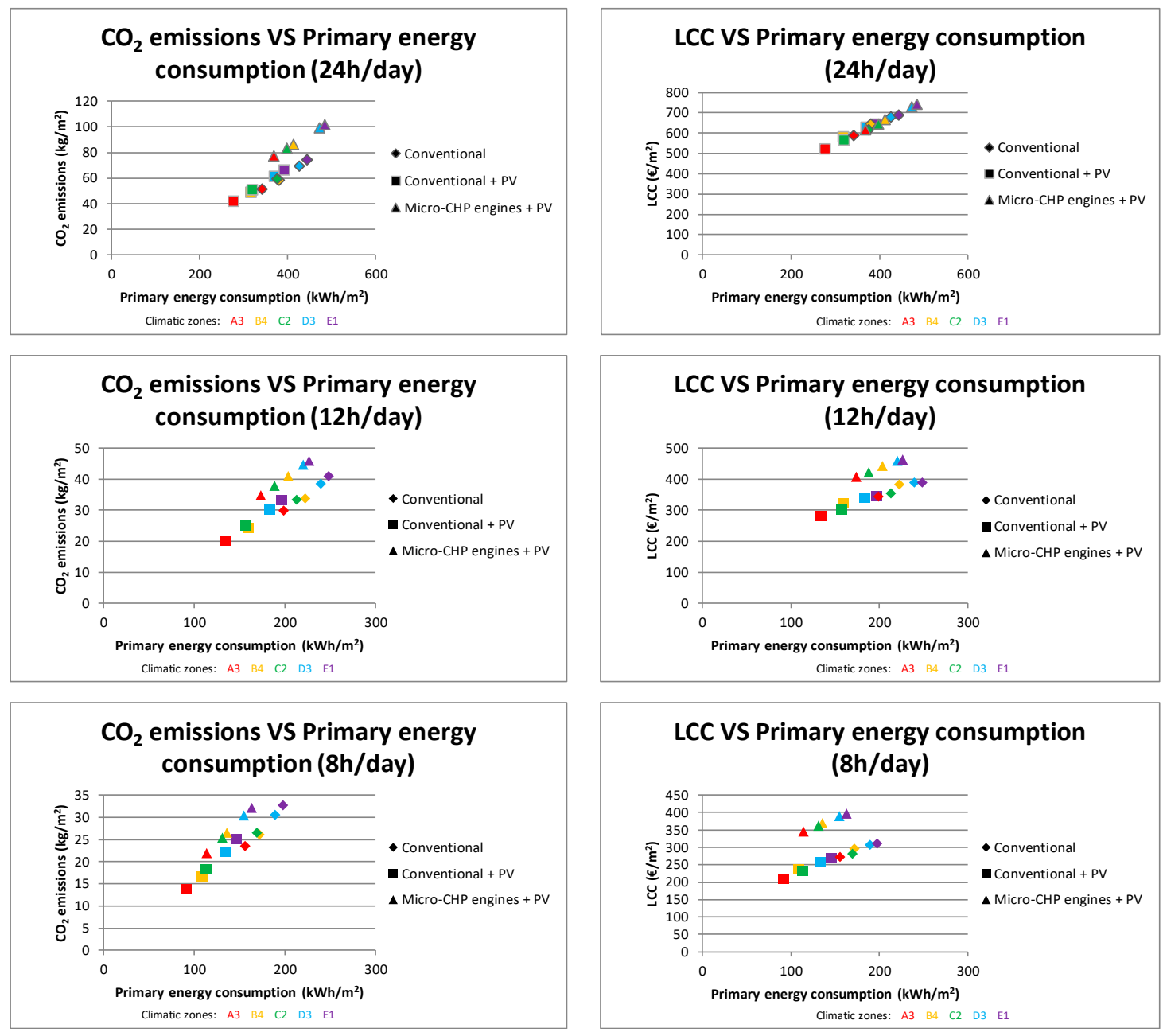

Figure 2. Emissions $\left[\mathrm{kgCO}_{2} / \mathrm{m}^{2}\right]$ vs primary energy-consumption $\left[\mathrm{kWh} / \mathrm{m}^{2}\right]$ (left) and LCC $\left[€ / \mathrm{m}^{2}\right]$ vs primary energy-consumption $\left[\mathrm{kWh} / \mathrm{m}^{2}\right]$ (right) for each climatic zone during a whole year.

\subsubsection{Primary Energy-Savings}

The first conclusion that the results show is that the primary energy-consumption of the conventional design is never the lowest among those considered. This is due to the fact that the conventional $+\mathrm{PV}$ case has the same gas natural consumption and a lower electricity consumption that the conventional case in all the climatic zones. On the other hand, the case with $\mu-\mathrm{CHP}+\mathrm{PV}$ has the highest energy consumption, since it has very high natural-gas consumption for the engines that do not compensate the reduction in the electric consumption. Therefore, the conventional case $+\mathrm{PV}$ is the one with the lowest primary energy-consumption, while $\mu-\mathrm{CHP}+\mathrm{PV}$ is the one with the highest consumption for all the climatic zones under study, when the building operates $24 \mathrm{~h}$ a day. When the building operates for fewer hours per day $(8$ or $12 \mathrm{~h})$, the natural-gas consumption of the engines is greatly reduced, thus reducing the energy consumption in the $\mu-\mathrm{CHP}+\mathrm{PV}$ strategy. This causes the conventional case to be the one with greater consumption, whereas conventional $+\mathrm{PV}$ is still the one with smaller consumption for all of the climatic zones. 


\subsubsection{Life-Cycle Costs}

The investment costs are lower in the conventional case than in the other two cases, due to the fact that there is no need to make any investments. On the other hand, the strategy with $\mu$-CHP + PV has a higher initial investment, due to the two natural gas engines.

The conventional case is also the strategy with lowest replacement costs, because the only system that should be replaced is the chiller, while for the other strategies the PV panels and the inverter should be also replaced. Also, maintenance costs are considered 3\% of the initial investment; therefore, these are lower in the conventional strategy and higher in the $\mu-\mathrm{CHP}+\mathrm{PV}$ case.

Finally, the cost of operation depends on the energy consumption in each case and climate zone, and on the electricity and natural gas prices. Due to the fact that the electricity price is three times higher than that of natural gas, the cases that consume more electricity are the ones with higher operating costs. Thus, the conventional case is the one with the highest operating costs, while $\mu-\mathrm{CHP}+$ PV has the lowest costs.

The LCC is higher in the $\mu-\mathrm{CHP}+\mathrm{PV}$ case, being followed by conventional and conventional + $\mathrm{PV}$. This is valid for all the climates and all the operational conditions of the building. The reason for this is that $\mu-\mathrm{CHP}+\mathrm{PV}$ is the case with the highest investment, maintenance, and replacement costs (followed by with conventional $+\mathrm{PV}$ ), which cannot be compensated even though the operation costs are lower.

Finally, the LCC is higher for each of the different strategies in those climatic zones in which the operating costs are higher (zones with higher energy consumption), that is, climatic zones E1, D3, and B4. This is because the only costs that vary between climates are the operation costs and the replacement costs, and the latter have a lower influence on the calculation of the LCC.

These outcomes allow one to draw the following conclusion, which goes hand in hand with that of many other studies: the technology of $\mu$-CHP engines is not yet economically feasible in certain disciplines, even though they are being implemented within buildings. Nevertheless, large-scale production could help reduce investment costs, which could dramatically modify the outlook.

\subsubsection{Emissions}

$\mathrm{CO}_{2}$ emissions are due to the energy consumption of both electricity and natural gas. Therefore, the emissions will be greater for those strategies and climatic zones with higher energy-consumptions. As in the previous case, the conventional $+\mathrm{PV}$ strategy has the lowest $\mathrm{CO}_{2}$ emissions, while $\mu$-CHP $+\mathrm{PV}$ is the case with higher emissions when the building operates $24 \mathrm{~h}$ a day. This is true for all the climates. On the other hand, for the building with an operation of $8 \mathrm{~h}$ per day or $12 \mathrm{~h}$ per day, conventional $+\mathrm{PV}$ continues to be the case with lowest emissions, while the conventional strategy is the one with the highest $\mathrm{CO}_{2}$ emissions.

\subsubsection{Optimum Design for Each Climatic Zone}

For each of the case studies that are analyzed, different criteria are evaluated in each climatic zone (primary energy-consumption, $\mathrm{CO}_{2}$ emissions, and LCC). In this way, it is possible to see which one is the most profitable option, which one has the lowest energy consumption, or which one has the lowest emissions in every climatic zone. Tables 5 and 6 show the order of preference for each case study, in which 1 is the best solution and 3 the worst. As it can be seen, considering the current energy prices, the most profitable alternative for any of the three parameters (LCC, primary energy-consumption, or emissions) is the same for all the climatic zones. In the case of the building with a $24 \mathrm{~h}$ operating schedule, the optimal choice would be the conventional case with PV modules, the second choice would be the conventional case, and the third would be the case with $\mu$-CHP engines combined with PV. For buildings that operate less time, 8 or $12 \mathrm{~h}$ a day, the conventional case would be the second choice regarding LCC but the third regarding primary energy-consumption and emissions. This is due 
to the fact that the natural-gas consumption of the $\mu$-CHP engines is lower than the consumption of the conventional case, but the initial costs are much higher.

Table 5. Preference of each design for each climate depending on the chosen criteria, valid for $24 \mathrm{~h}$ of operation of the building a day. 1 is the best solution and 3 the worst.

\begin{tabular}{ccccccc}
\hline Design & CRITERIA & A3 & B4 & C2 & D3 & E1 \\
\hline \multirow{3}{*}{ Conventional case } & LCC & 2 & 2 & 2 & 2 & 2 \\
& PRIMARY ENERGY & 2 & 2 & 2 & 2 & 2 \\
& EMISSIONS & 2 & 2 & 2 & 2 & 2 \\
\hline \multirow{3}{*}{ Conventional + PV } & LRIMARY ENERGY & 1 & 1 & 1 & 1 & 1 \\
& EMISSIONS & 1 & 1 & 1 & 1 & 1 \\
\hline \multirow{3}{*}{-CHP engines + PV } & PRIMARY ENERGY & 3 & 3 & 3 & 3 & 3 \\
& EMISSIONS & 3 & 3 & 3 & 3 & 3 \\
\hline
\end{tabular}

Table 6. Preference of each design for each climate depending on the chosen criteria, valid for both 8 and $12 \mathrm{~h}$ of operation of the building a day. 1 is the best solution and 3 the worst.

\begin{tabular}{ccccccc}
\hline Design & CRITERIA & A3 & B4 & C2 & D3 & E1 \\
\hline \multirow{3}{*}{ Conventional case } & LCC & 2 & 2 & 2 & 2 & 2 \\
& PRIMARY ENERGY & 3 & 3 & 3 & 3 & 3 \\
& EMISSIONS & 3 & 3 & 3 & 3 & 3 \\
\hline \multirow{3}{*}{ Conventional + PV } & LCC & 1 & 1 & 1 & 1 & 1 \\
& PRIMARY ENERGY & 1 & 1 & 1 & 1 & 1 \\
& EMISSIONS & 1 & 1 & 1 & 1 & 1 \\
\hline \multirow{3}{*}{-CHP engines + PV } & PRIMARY ENERGY & 2 & 2 & 2 & 2 & 2 \\
& EMISSIONS & 2 & 2 & 2 & 2 & 2 \\
\hline
\end{tabular}

\subsection{Sensitivity Analysis}

A sensitivity analysis was considered appropriate to determine what the results would be if the energy prices and the costs of the CHP-engines, inverter, and PV modules were different, which is likely to occur in the near future. Several scenarios have been considered (Figure 3).

Decreasing the electricity price or increasing the natural gas price does not modify the optimal cases shown in Table 6; thus, the conventional + PV strategy continues to be the case with the lowest costs, while $\mu-\mathrm{CHP}+\mathrm{PV}$ is the case with the highest costs. On the other hand, increasing the electricity price or decreasing the price of natural gas does cause changes, which are expressed in Figure 3 considering a 24-h building operation schedule. This figure only shows the results in terms of the LCC, since the optimal options according to energy consumption and $\mathrm{CO}_{2}$ emissions do not vary with respect to the tables in the previous section. If the prices of the $\mu-\mathrm{CHP}$ engines were reduced $60 \%$, the scenario with $\mu$-CHP engines and PV modules would be the most profitable one in the climatic zones B4 and C2. On the other hand, if the costs of the inverter and the PV modules were reduced by $60 \%$, the only change that would be observed compared to the previous scenario would be that the system with $\mu$-CHP engines and PV modules would become the second-best option in the climatic zone B4, while conventional + PV would still be the most profitable option in all the climatic zones. 


\begin{tabular}{|c|c|c|c|c|c|c|}
\hline SCENARIO & STRATEGY & A3 & B4 & C2 & D3 & E1 \\
\hline \multirow{3}{*}{ Previous scenario } & Conventional case & 2 & 2 & 2 & 2 & 2 \\
\cline { 2 - 7 } & Conventional + PV & 1 & 1 & 1 & 1 & 1 \\
\cline { 2 - 7 } & Micro-CHP engines + PV & 3 & 3 & 3 & 3 & 3 \\
\hline \multirow{3}{*}{ Electricity Price (+20\%) } & Conventional case & 3 & 3 & 3 & 3 & 3 \\
\cline { 2 - 7 } & Conventional + PV & 1 & 2 & 2 & 1 & 1 \\
\cline { 2 - 7 } & Micro-CHP engines + PV & 2 & 1 & 1 & 2 & 2 \\
\hline \multirow{3}{*}{ Electricity Price (+40\%) } & Conventional case & 3 & 3 & 3 & 3 & 3 \\
\cline { 2 - 6 } & Conventional + PV & 2 & 2 & 2 & 2 & 2 \\
\cline { 2 - 7 } & Micro-CHP engines + PV & 1 & 1 & 1 & 1 & 1 \\
\hline \multirow{3}{*}{ Natural Gas Price (-20\%) } & Conventional case & 3 & 3 & 3 & 3 & 3 \\
\cline { 2 - 6 } & Conventional + PV & 1 & 2 & 1 & 1 & 1 \\
\cline { 2 - 6 } & Micro-CHP engines + PV & 2 & 1 & 2 & 2 & 2 \\
\hline \multirow{3}{*}{ Natural Gas Price (-40\%) } & Conventional case & 3 & 3 & 3 & 3 & 3 \\
\cline { 2 - 6 } & Conventional + PV & 2 & 2 & 2 & 2 & 2 \\
\cline { 2 - 6 } & Micro-CHP engines + PV & 1 & 1 & 1 & 1 & 1 \\
\hline \multirow{3}{*}{ Micro-CHP engines Price (-60\%) } & Conventional case & 3 & 3 & 3 & 3 & 3 \\
\cline { 2 - 6 } & Conventional + PV & 1 & 2 & 2 & 1 & 1 \\
\cline { 2 - 6 } & Micro-CHP engines + PV & 2 & 1 & 1 & 2 & 2 \\
\hline \multirow{3}{*}{ Inverter and PV panels Price (-60\%) } & Conventional case & 2 & 3 & 2 & 2 & 2 \\
\cline { 2 - 6 } & Conventional + PV & 1 & 1 & 1 & 1 & 1 \\
\cline { 2 - 6 } & Micro-CHP engines + PV & 3 & 2 & 3 & 3 & 3 \\
\hline
\end{tabular}

Figure 3. Sensitivity analysis when changing prices for the building with a $24 \mathrm{~h}$ operation. (Red corresponds to the worst strategies, yellow for intermediate ones, and green for the best ones.)

\section{Conclusions}

In the present work, a representative tertiary office building in Spain has been used as a case study with the purpose of evaluating two designs of hybrid systems through very detailed simulations. These systems integrate renewable resources together with CHP engines, supplying the necessary electricity, heating, and cooling for the building. Calculations have been performed in order to compare the primary energy-consumption, emissions, and LCC for the considered designs and climates. A set of tables showing the preference for each case study depending on these criteria and the hours of operation of the building has been presented to define the optimal solutions.

Comparing the different designs that have been studied, the conventional $+\mathrm{PV}$ is the ideal installation in terms of energy consumption, $\mathrm{CO}_{2}$ emissions, and LCC for each of the different building's hours of operation considered. From the sensitivity analysis, it is concluded that the prices of energy (electricity and natural gas) have a greater influence on the LCC than the prices of the equipment ( $\mu$-CHP engines, PV panels, and inverters). The price of electricity would have to rise by $20 \%$ so that the $\mu$-CHP + PV strategy would be optimal in terms of LCC in some climatic zones (B4 and C2), and until it rises to $40 \%$ it would not be optimal in all climates. In addition, either the price of natural gas would have to go down by $20 \%$ so that $\mu$-CHP was the optimal strategy in terms of LCC in the climate zone B4, or by $40 \%$ to be optimal in all climates. However, these scenarios might be unrealistic in the medium term.

In addition, in terms of primary energy-consumption and emissions the optimal case is always the conventional + PV strategy, which leads us to the conclusion that this is the most promising strategy in the immediate future for office buildings. This contrasts with the results obtained for the residential buildings in [45], in which the conventional case was the optimal one in terms of LCC in all climates, and the $\mu-\mathrm{CHP}+\mathrm{PV}+$ solar thermal was the optimal one in terms of primary energy-consumption and emissions in all climatic zones.

The results show that more work is needed. Governments need to address the removal of administrative barriers, and manufacturers should also intervene due to the high costs of the engines, for example, which could be lowered through technological innovations allowed by economies of scale. The importance of climate has also been highlighted when choosing the optimal designs. Studies such as the one proposed in the present work are necessary in order to achieve more energy-efficient installations, especially in tertiary buildings due to their high energy consumptions. 
Author Contributions: Conceptualization, J.M.S.L. and L.R.R.; Methodology, F.D.P. and L.R.R.; Software, F.D.P.; Validation, all; Formal Analysis, J.M.S.L., L.R.R. and F.J.S.d.1.F.; Investigation, all; Writing-Original Draft Preparation, F.D.P. and L.R.R.; Writing-Review \& Editing, L.R.R.; Supervision, J.M.S.L. and F.J.S.d.l.F.

Funding: This research received no external funding.

Conflicts of Interest: The authors declare no conflict of interest.

\section{References}

1. Milewski, J.; Szabłowski, Ł.; Kuta, J. Control strategy for an internal combustion engine fuelled by natural gas operating in distributed generation. Energy Procedia 2012, 14, 1478-1483. [CrossRef]

2. Williams, M.C.; Strakey, J.P.; Singhal, S.C. U.S. distributed generation fuel cell program. J. Power Sources 2004, 131, 79-85. [CrossRef]

3. Kuhn, V.; Klemeš, J.; Bulatov, I. MicroCHP: Overview of selected technologies, products and field test results. Appl. Therm. Eng. 2008, 28, 2039-2048. [CrossRef]

4. Entchev, E.; Yang, L.; Szadkowski, F.; Armstrong, M.; Swinton, M. Application of hybrid micro-cogeneration system-Thermal and power energy solutions for Canadian residences. Energy Build. 2013, 60, 345-354. [CrossRef]

5. Ehyaei, M.A.; Ahmadi, P.; Atabi, F.; Heibati, M.R.; Khorshidvand, M. Feasibility study of applying internal combustion engines in residential buildings by exergy, economic and environmental analysis. Energy Build. 2012, 55, 405-413. [CrossRef]

6. Nosrat, A.H.; Swan, L.G.; Pearce, J.M. Improved performance of hybrid photovoltaic-trigeneration systems over photovoltaic-cogen systems including effects of battery storage. Energy 2013, 49, 366-374. [CrossRef]

7. Dekker, J.; Nthontho, M.; Chowdhury, S.; Chowdhury, S.P. Economic analysis of PV/diesel hybrid power systems in different climatic zones of South Africa. Int. J. Electr. Power Energy Syst. 2012, 40, 104-112. [CrossRef]

8. Kaldellis, J.; Zafirakis, D.; Kavadias, K.; Kondili, E. Optimum PV-diesel hybrid systems for remote consumers of the Greek territory. Appl. Energy 2012, 97, 61-67. [CrossRef]

9. Kaabeche, A.; Ibtiouen, R. Techno-economic optimization of hybrid photovoltaic/wind/diesel/battery generation in a stand-alone power system. Sol. Energy 2014, 103, 171-182. [CrossRef]

10. Tazvinga, H.; Xia, X.; Zhang, J. Minimum cost solution of photovoltaic-diesel-battery hybrid power systems for remote consumers. Sol. Energy 2013, 96, 292-299. [CrossRef]

11. Agarwal, N.; Kumar, A. Varun Optimization of grid independent hybrid PV-diesel-battery system for power generation in remote villages of Uttar Pradesh, India. Energy Sustain. Dev. 2013, 17, 210-219. [CrossRef]

12. Bianchi, M.; De Pascale, A.; Melino, F. Performance analysis of an integrated CHP system with thermal and Electric Energy Storage for residential application. Appl. Energy 2013, 112, 928-938. [CrossRef]

13. Nosrat, A.H.; Swan, L.G.; Pearce, J.M. Simulations of greenhouse gas emission reductions from low-cost hybrid solar photovoltaic and cogeneration systems for new communities. Sustain. Energy Technol. Assess. 2014, 8, 34-41. [CrossRef]

14. Conroy, G.; Duffy, A.; Ayompe, L.M. Economic, energy and GHG emissions performance evaluation of a WhisperGen Mk IV Stirling engine $\mu$-CHP unit in a domestic dwelling. Energy Convers. Manag. 2014, 81, 465-474. [CrossRef]

15. Budzianowski, W.M. Negative Net $\mathrm{CO}(2)$ Emissions from Oxy-Decarbonization of Biogas to $\mathrm{H}(2)$. Int. J. Chem. React. Eng. 2010, 8. [CrossRef]

16. Zhao, X.L.; Fu, L.; Zhang, S.G.; Jiang, Y.; Li, H. Performance improvement of a $70 \mathrm{kWe}$ natural gas combined heat and power (CHP) system. Energy 2010, 35, 1848-1853. [CrossRef]

17. Campos Celador, A.; Odriozola, M.; Sala, J.M. Implications of the modelling of stratified hot water storage tanks in the simulation of CHP plants. Energy Convers. Manag. 2011, 52, 3018-3026. [CrossRef]

18. Jiang, F.; Xie, H.; Ellen, O. Hybrid Energy System with Optimized Storage for Improvement of Sustainability in a Small Town. Sustainability 2018, 10, 2034. [CrossRef]

19. Barelli, L.; Bidini, G.; Bonucci, F.; Castellini, L.; Castellini, S.; Ottaviano, A.; Pelosi, D.; Zuccari, A. Dynamic Analysis of a Hybrid Energy Storage System (H-ESS) Coupled to a Photovoltaic (PV) Plant. Energies 2018, 11. [CrossRef] 
20. D'Adamo, I. The Profitability of Residential Photovoltaic Systems. A New Scheme of Subsidies Based on the Price of $\mathrm{CO}_{2}$ in a Developed PV Market. Soc. Sci. 2018, 7, 148. [CrossRef]

21. Kim, J.; Kim, E.J. Simplified method of optimal sizing of a renewable energy hybrid system for schools. Sustainability 2016, 8. [CrossRef]

22. Araújo, C.; Almeida, M.; Bragança, L.; Barbosa, J.A. Cost-benefit analysis method for building solutions. Appl. Energy 2016, 124-133. [CrossRef]

23. Barbieri, E.S.; Melino, F.; Morini, M. Influence of the thermal energy storage on the profitability of micro-CHP systems for residential building applications. Appl. Energy 2012, 97, 714-722. [CrossRef]

24. Lee, H.; Bush, J.; Hwang, Y.; Radermacher, R. Modeling of micro-CHP (combined heat and power) unit and evaluation of system performance in building application in United States. Energy 2013, 58, 364-375. [CrossRef]

25. Cao, S.; Mohamed, A.; Hasan, A.; Sirén, K. Energy matching analysis of on-site micro-cogeneration for a single-family house with thermal and electrical tracking strategies. Energy Build. 2014, 68, 351-363. [CrossRef]

26. McHenry, M.P. A technical, economic, and greenhouse gas emission analysis of a homestead-scale grid-connected and stand-alone photovoltaic and diesel systems, against electricity network extension. Renew. Energy 2012, 38, 126-135. [CrossRef]

27. Hamada, Y.; Takeda, K.; Goto, R.; Kubota, H. Hybrid utilization of renewable energy and fuel cells for residential energy systems. Energy Build. 2011, 43, 3680-3684. [CrossRef]

28. Zheng, X.; Wu, G.; Qiu, Y.; Zhan, X.; Shah, N.; Li, N.; Zhao, Y. A MINLP multi-objective optimization model for operational planning of a case study CCHP system in urban China. Appl. Energy 2018, 210, 1126-1140. [CrossRef]

29. Villar, C.H.; Neves, D.; Silva, C.A. Solar PV self-consumption: An analysis of influencing indicators in the Portuguese context. Energy Strateg. Rev. 2017, 224-234. [CrossRef]

30. Khanmirza, E.; Esmaeilzadeh, A.; Markazi, A.H.D. Design and experimental evaluation of model predictive control vs. intelligent methods for domestic heating systems. Energy Build. 2017. [CrossRef]

31. Kneiske, T.M.; Braun, M. Flexibility potentials of a combined use of heat storages and batteries in PV-CHP hybrid systems. Energy Procedia 2017, 135, 482-495. [CrossRef]

32. Ahmad, J.; Imran, M.; Khalid, A.; Iqbal, W.; Ashraf, S.R.; Adnan, M.; Ali, S.F.; Khokhar, K.S. Techno economic analysis of a wind-photovoltaic-biomass hybrid renewable energy system for rural electrification: A case study of Kallar Kahar. Energy 2018, 148, 208-234. [CrossRef]

33. Kasaeian, A.; Khanjari, Y.; Golzari, S.; Mahian, O.; Wongwises, S. Effects of forced convection on the performance of a photovoltaic thermal system: An experimental study. Exp. Therm. Fluid Sci. 2017, 13-21. [CrossRef]

34. Ghasemi, A.; Asrari, A.; Zarif, M.; Abdelwahed, S. Techno-economic analysis of stand-alone hybrid photovoltaic-diesel-battery systems for rural electrification in eastern part of Iran-A step toward sustainable rural development. Renew. Sustain. Energy Rev. 2013, 28, 456-462. [CrossRef]

35. Ma, T.; Yang, H.; Lu, L. A feasibility study of a stand-alone hybrid solar-wind-battery system for a remote island. Appl. Energy 2014, 121, 149-158. [CrossRef]

36. Kneiske, T.M.; Braun, M.; Hidalgo-Rodriguez, D.I. A new combined control algorithm for PV-CHP hybrid systems. Appl. Energy 2018, 964-973. [CrossRef]

37. Liu, H.; Zhang, X.; Ou, X. Life Cycle Analysis of Distributed Energy System Projects' Energy Consumption and GHG Emission-A Case of Beer Brewery Auxiliary Power Supply in China. Energy Procedia 2017, 105, 3456-3463.

38. Pichel, N.; Vivar, M.; Fuentes, M. Performance analysis of a solar photovoltaic hybrid system for electricity generation and simultaneous water disinfection of wild bacteria strains. Appl. Energy 2016, 103-112. [CrossRef]

39. Pichel, N.; Vivar, M.; Fuentes, M. Performance study of a hybrid photovoltaic and solar water disinfection system considering climatic variations over a year. Energy Convers. Manag. 2017, 312-321. [CrossRef]

40. Li, C.; Wang, H.; Miao, H.; Ye, B. The economic and social performance of integrated photovoltaic and agricultural greenhouses systems: Case study in China. Appl. Energy 2017, 204-212. [CrossRef]

41. Fani, M.; Sadreddin, A. Solar assisted CCHP system, energetic, economic and environmental analysis, case study: Educational office buildings. Energy Build. 2017, 100-109. [CrossRef] 
42. Yousefi, H.; Ghodusinejad, M.H.; Kasaeian, A. Multi-objective optimal component sizing of a hybrid ICE + PV/T driven CCHP microgrid. Appl. Therm. Eng. 2017, 122, 126-138. [CrossRef]

43. Kasaeian, A.; Nouri, G.; Ranjbaran, P.; Wen, D. Solar collectors and photovoltaics as combined heat and power systems: A critical review. Energy Convers. Manag. 2018, 156, 688-705. [CrossRef]

44. Salmerón, J.M.; Álvarez, S.; Molina, J.L.; Ruiz, A.; Sánchez, F.J. Tightening the energy consumptions of buildings depending on their typology and on Climate Severity Indexes. Energy Build. 2013, 58, 372-377. [CrossRef]

45. Romero Rodríguez, L.; Salmerón Lissén, J.M.; Sánchez Ramos, J.; Rodríguez Jara, E.Á.; Álvarez Domínguez, S. Analysis of the economic feasibility and reduction of a building's energy consumption and emissions when integrating hybrid solar thermal/PV/micro-CHP systems. Appl. Energy 2016, 165. [CrossRef]

46. Ministerio de Fomento. LIDER Software; Government of Spain: Madrid, Spain, 2009.

47. Factores de Emisión de CO2 y Coeficientes de Paso a Energía Primaria de Diferentes Fuentes de Energía Final Consumidas en el Sector de Edificios en España. Available online: http://www.minetad.gob.es/energia/ desarrollo/EficienciaEnergetica/RITE/Reconocidos/Reconocidos/Otrosdocumentos/Factores_emision_CO2. pdf (accessed on 1 October 2018).

48. Klein, S.A. TRNSYS 17: A Transient System Simulation Program; Engineering Experiment Station Report; University of Wisconsin-Madison: Madison, WI, USA, 2010.

(C) 2018 by the authors. Licensee MDPI, Basel, Switzerland. This article is an open access article distributed under the terms and conditions of the Creative Commons Attribution (CC BY) license (http:/ / creativecommons.org/licenses/by/4.0/). 